\title{
Performance and carcass and organ weights of broiler chicks fed graded levels of Acha grains (Digitaria exilis)
}

\author{
${ }^{1}$ Ukim, C.I., ${ }^{2}$ Ojewola, G S. and ${ }^{3}$ Obun, C. O., ${ }^{4}$ Ndelekwute, E. N \\ ${ }^{I}$ Nigerian Institute of Animal Science, Salt Lake Street, Maitama, Abuja, Nigeria. \\ ${ }^{2}$ Departments of Animal Science, Michael Okpara University of Agriculture, Umudike, Abia State, Nigeria. \\ ${ }^{3}$ Department of Animal production, Federal College of Wildlife Management, New Bussa, Niger State, Nigeria. \\ ${ }^{4}$ Department of Animal Science, University of Uyo, Akwa Ibom State, Nigeria
}

\begin{abstract}
The effects of replacing 0, 25, 50, 75 and 100\% of maize with Acha grains in broiler chicks' diets on growth performance, apparent digestibility coefficient $(A D C)$ and carcass and organ weights was studied in a 8 week experiment using 150 unsexed 7 days-old Abor-Acre broiler chicks. The results showed that Acha grains could be used to replaced maize up to 100\% without significantly $(P>0.05)$ affecting body weight gain, ADC and percentage carcass and cut-up parts and organ weights of finisher broilers, except the abdominal fat deposit. Acha grains is therefore recommended for use to replace maize as a good energy source in poultry rations.
\end{abstract}

Key words: Acha grains, growth rate, digestibility, carcass, broiler chicks

\section{Introduction}

Maize is the major source of energy in poultry feeds and constitutes about $60 \%$ in poultry diet (1). Unfortunately, the rapid growth of human population has intensified the competition between man and livestock for these cereal grains resulting in high cost of feeds and consequently high prices of poultry products leading to very low levels of protein intake in most developing countries. Consequent upon the increased in poultry production cost, research attention is now geared towards lesser known cereal ingredients that will not compromise the feed quality. One of such cereal grain is Acha.

"Acha"(Digitaria exilis) commonly referred to as fonio, finni, hungry rice $(2 ; 3 ; 4 ; 5)$, is probably one of the oldest Africa cereals dating back to 7,000 years $(6 ; 7)$ and classified as one of the lost crops of Africa. Acha crops are exceptionally tolerant to a wide variety of conditions, particularly drought and poor soil (6).

Feeding cereal grains (Sorghum, Oats, Millets and Triticale) as replacement for maize-based diets to broilers have not been reported to have any adverse effect on the carcass and organ weights (liver, heart, lungs, kidney and gizzard) ( 8;9). (9) reported that millet and sorghum can be well-utilized to produce broiler chickens with superior carcass quality compared to maize. The fibre content of acha is lower than the values for sorghum and maize but higher than those for millet and rice (10). Broilers with better developed breast meat are considered superior while heavy deposits of abdominal fat in finished broilers indicate poor finishing. (9) reported that millet and sorghum can be well-utilized to produce broiler chickens with superior carcass quality compared to maize. Despite its ancient heritage and widespread importance, acha has received little utilization attention compared to sorghum, pearl millet and maize.

There is limited reference work on the utilization and inclusion of acha grains as an alternative energy source in poultry production. The objective of this study was to evaluate the performance and carcass and organ weights of birds fed graded levels of acha grains.

\section{Materials And Methods}

\subsection{Experimental Site}

The experiment was conducted at the Poultry Unit of the Teaching and Research Farm of the College of Animal Science and Production, Michael Okpara University of Agriculture, Umudike, Abia State, Nigeria. Umudike is located at latitude $5^{0} 29^{\prime} \mathrm{N}$ and Longitude $7^{0} 32^{\prime} \mathrm{E}$ in the rain forest zone of Nigeria (11).

\subsection{Source of Acha (Digitaria exilis) Grains}

The Acha (Digitaria exilis) grains were purchased from Jos Central Market, Plateau State, Nigeria. The acha grains were manually cleaned by hand picking of the chaffs. 
Performance and carcass and organ weights of broiler chicks fed graded levels of Acha grains

2.3. Experimental Diets

Five broiler starter diets were formulated with acha grains directly replacing maize at graded levels of $0,25,50,75$, and 100\%, respectively in Tables 1 and 2 and designated as $T_{1}, T_{2}, T_{3}, T_{4}$ and $T_{5}$ respectively.

\subsection{Source of Experimental Birds and design}

One hundred and fifty day-old Abor-Acre broiler chicks were purchased from Ibadan, Oyo State, Nigeria. After one week of brooding with commercial diets, birds were equally distributed to five experimental dietary treatments of 30 chicks each, replicated three times (10 birds each) in a completely randomize design (CRD)

\subsection{Management of Experimental Birds}

The chicks were raised on deep litter floor using wood shavings as litter material. Brooding was by means of kerosene stove as source of heat placed under a hover. Temperature of the brooding room was controlled by either reducing or increasing the flame of the stove or outright removal after reading the thermometer. On arrival at the farm, glucose was added to the birds' drinking water as anti stress. Birds were intra-ocularly vaccinated against Newcastle disease on the third day. Lasota vaccine was administered on the $14^{\text {th }}$ and $28^{\text {th }}$ day while infectious bursal disease vaccine (Gumboro) was administered on the $12^{\text {th }}$ and $19^{\text {th }}$ day. Birds were protected against coccidiosis from the $15^{\text {th }}-21^{\text {st }}$ days using Amprolium drug. At 28 days, starter diet was switched over to finisher diets and fed for another 28 days.

\subsection{Feed Intake and Growth Parameters Measurements}

Data on body weight and feed intake were collected weekly. Body weights of birds were individually weighed weekly in each replicate. The quantity of feed fed to the birds was measured and recorded on daily basis and the left over subtracted from the quantity fed the previous day to determine the quantity consumed by each replicate.

\subsection{Digestibility Trial}

At the end of feeding trial, three birds each from the five treatment groups were randomly selected from each replicate and then transferred into metabolic cages for faecal collection. The birds were placed in metabolic cages with facilities for feed and water. They were allowed to acclimatize for a period of four days. Thereafter, total faecal collection was made for three days by means of clean trays placed under the cages. Collected faecal samples were immediately oven dried to constant weight at $60^{\circ} \mathrm{C}$. Each dried treatment sample was bulked and ground to fine particles and stored for proximate analysis.

\subsection{Evaluation of carcass and organ weights}

At the end of the feeding trial (56 days), three birds per replicate were randomly selected, starved overnight, weighed and slaughtered. The birds were bled and dipped into a warm water $\left(60^{\circ} \mathrm{C}\right)$ bath for 5 minutes, feather-plucked after scalding and eviscerated. The carcass, and visceral organs (liver, heart, gizzard and pancreas) were removed and expressed as percentage of live weights.

\subsection{Chemical Assay}

The diets and faecal droppings were analyzed for proximate composition according to (12) methods.

\subsection{Data Analyses}

All data collected were subjected to Analysis of variance (ANOVA) as outlined by (13). Means were separated using Duncan's New Multiple Range Test (14).

\subsection{Performance of broiler chicks}

\section{Results}

The birds fed diet $\mathrm{T}_{5}$ had the highest $(\mathrm{P}<00.05)$ feed intake compared with those on diets $\mathrm{T}_{1}, \mathrm{~T}_{2}, \mathrm{~T}_{3}$ and $\mathrm{T}_{4}$ as presented in Table 3. Birds fed diet $\mathrm{T}_{4}$ had the highest weight gain value of $1998.52 \mathrm{~g}$ while those on diet $\mathrm{T}_{1}$ had the least value of $1735 \mathrm{~g}$. 
Performance and carcass and organ weights of broiler chicks fed graded levels of Acha grains

\subsection{Digestibility coefficient of experimental birds fed to broiler chicks}

The result of the apparent digestibility coefficients (ADC) of experimental birds fed graded levels of acha grain is presented in Table 4 . The ADC values for dry matter, crude protein, crude fibre, ash and nitrogen free extracts were not significantly $(\mathrm{P}>0.05)$ affected across the dietary treatments except for ether extract.

\subsection{Carcass and organ weights of broilers fed experimental diets}

The percentage carcass weights and cut-up part measurements expressed as percentages of live weights are presented in Table 5. Replacing maize with acha grains (AG) up to $100 \%$ levels in the diet of broiler chicks did not affect $(\mathrm{P}>0.05)$ carcass and edible parts yield except for abdominal fat which was significantly $(\mathrm{P}<0.05)$ lower in maize based-diets compared to acha grain-based diets.

\subsection{Organ weights of finisher broiler chicks fed experimental diets}

The results of organ measurements depicted in Table 6 showed no significant $(\mathrm{P}>0.05)$ effects on heart, kidney, lungs, pancreas and spleen. The percentage organ weights of gizzard, liver and proventriculus were significantly $(\mathrm{P}<0.05)$ higher in birds on diets $\mathrm{T}_{4}$ and $\mathrm{T}_{5}$ compared with lower values from other treatment groups

\section{Discussion}

The significant $(\mathrm{p}<0.05)$ decreased in feed intake of birds on diets $\mathrm{T}_{1}, \mathrm{~T}_{2}$ and $\mathrm{T}_{3}$ could be due to their low live body weights which determine the rate of feed consumption. The relative higher body weights of the birds on acha grains at $75 \%\left(\mathrm{~T}_{4}\right)$ and $100 \%\left(\mathrm{~T}_{5}\right)$ agreed with the reports of (3) that the crude protein content and amino acid profile in acha grains (AG) may have stimulated a better growth response that was proportionate to the concentration of the acha grains in the diets. The superior growth of birds on 75 and $100 \%$ AG based diets is in conformity with the findings of $(8 ; 15 ; 16 ; 17$ and 18$)$ who stated that all the dietary maize portion of broiler diets can be replaced with low-tannin sorghum and millet (similar cereals to acha grains) without adverse effects on live weights gain, feed intake and feed conversion ratio.

The non significant differences in percentage carcass weights and cut-up parts are in conformity with results obtained by (19) who fed pearl millet grains to broilers. The breast and abdominal fat components of finished broilers are very important in assessing feed quality. Broilers with better developed breast meat are considered superior while heavy deposit of abdominal fat in broilers indicates poor finishing product. The adipose depositions in birds fed diets with increasing AG is in agreement with reports by (20) that dietary feed intake is mobilized for rapid growth in young birds, while the older birds have the tendency of storing excess energy in the form of fat which corresponded with high feed intake of these groups of birds. Since birds primarily eat to satisfy their energy requirement, excess energy consumption would most likely be stored as fat in birds.

The slight increases in organ weights with increasing AG in the diets may have resulted from their heavy live weights as reported by (21) since the surface area and the live weights determine the amount of feathers and visceral organs required. This finding is in agreement with previous reports by $(22 ; 23$ and 24) who fed broilers with whole grains of wheat, triticale, and barley.

\section{Conclusion}

In conclusion of this study, acha grains could be use in period of maize scarcity as an alternative energy source. However, further studies on large number and other breeds of poultry need to be carried out before acha grains could be given priority to replace maize completely.

\section{References}

[1] C O. Obun and E E. Abia. Performance and hematological changes of broiler chicks fed. Agro-

chemical treated maize. Journal of Sustainable Agric and the Environment, Umudike, Abia State Vol. 5 (2), 2003,313-318pp

[2] K O. Rachie, The millet and minor cereals: A bibliography of the world literature in millets processing 1930 and 1964-69 and all literature on other minor cereals. The Scarecrew Pres Inc. Metuchen, NJ., 1974, 564.

[3] I A, Jideani and J. Akingbola, Some physical, chemical properties of Acha (D. exilis) and Iburu (D. Abura) grain. J. Sc. Food Agric. 63, 1993, $369-373$.

[4] E H. Kwon-Ndung and S M. Misari, Overview of research and development of fonio (Digitaria exilis Kippis Stapf) and prospect for improvement in Nigeria. In: Genetics and food security in Nigeria. GNS Publication, Nigeria, 1999, 71-76.

[5] A. Ibrahim, Hungry rice (Fonio): A neglected cereal crop. NAQAS Newsletter, 2001, Vol. 4-5.

[6] National Academy of Sciences (NAS) Lost Crops of Africa: Volume I: Grains. Washington, D.C.: National Academy Press, 1996

[7] J F.Cruz, Fonio: a small grain with potential. In: Magazine on Low External Input and Sustainable Agriculture (LEISA). Vol. 20(1), 2004,16-17.

[8] M A. Hidalgo, A J. Davis, A M. Dale and W A. Dozier, Use of Whole Pearl Millet in Broiler Diets. J. Appl. Poult. Res. 13, 2004, $229-234$. 
[9] C I. Medugu, I D. Kwari, J. Igwebuike, I. Nkama, I D. Mohammed and B. Hamaker, Carcass and blood components of broiler chickens fed sorghum or millet as replacement for maize in the semi arid zone of Nigeria. Agric. Biol. Jour. Nutr. Amer. 1(3)2010: 326-329

[10] O. Chukwu and A J. Abdul-kadir, Proximate Chemical Composition of Acha (Digitaria exilis and Digitaria iburua) Grains. Jour. Food Tech. 6 (5), 2008, 214-216.

[11] National Root Crops Research Institute (NRCRI), National Root Crops Research Institute Weather Chart, Meteorology Unit, 2003.

[12] Association of Official Analytical Chemists (A.O.A.C), Official Methods of Analysis. 15 ${ }^{\text {th }}$ ed. Washington, D.C Association of Analytical Chemistry, 1990, 1546

[13] R G D. Steel, R and J H. Torrie, Principles and Procedures of Statistics: A Biometrical Approach, $2^{\text {nd }}$ ed. McGraw Hill Books Co. Inc. New York, 1980, 63p.

[14] D G. Duncan, Multiple Range and Multiple F-tests. Biometrics II, 1955, 1-42

[15] M. Gualitieri and S. Rapaccinni, Sorghum grains in poultry feeding. World's Poultry Sci. J 46, 1990, $246-254$.

[16] J P. Jacob, N. Mitaru, P N. Mbugu and R. Blair, The effect of substituting Kenyan serena sorghum for maize in broiler chicken s starter diets with different dietary protein and methionine levels. Animal Feed Sci. Technol. 61, 996, 41-56.

[17] J. Pour-Reza and M A. Edriss, Effects of dietary sorghum of different tannin concentration and tallow supplementation on the performance of broiler chicks. British Poult. Sc. 38, 1997, 512.

[18] A. Abubakar, A. Bello, M. Tukur and Y.A. Bashar, Whole millet in the diets of broiler starters in a semi-arid environment of Nigeria. In: Proc. $36^{\text {th }}$ Ann. Conf. Niger. Soc. Anim. Prod. (NSAP) 13-16 ${ }^{\text {th }}$ March, 2011. Uniabuja. (Edited by A. A. Adeniji, E.A.Olatunji and E.S.Gana), 2011, 359-362.

[19] A J. Davis, N M. Dale. and F. J. Ferreira, Pearl millet as an alternative feed ingredient in broiler diets. J. Appl. Poult. Res. 12, 2003, 137-144.

[20] S N. Ibe, Effects of feed restriction on principle component measures of body size and conformation in commercial broiler chickens. Niger. Jour. of Anim. Prod. 17,(10), 1990, 1-5pp.

[21] L A.Broadbent, B J. Wilson and C. Fisher,. The composition of broiler chicken at 56 days of age: Output components and chemical composition. British Poultry Science. 22, 1981, 4 -10

[22] B. Svihus, O. Herstad, C W. Newman and R K. Newman, Comparison of performance and intestinal characteristics of broiler chickens fed on diets containing whole, rolled or ground barley. Br. Poult. Sci. 38, 1997, 524-529.

[23] G.P.D. Jones and R D.Taylor, The incorporation of whole grain into pelleted broiler chicken diets: Production and physiological responses. Br. Poult. Sci. 42, 200, 477-483.

[24] M A. Al-Harthi, Efficiency of utilizing some species and herbs with or without antibiotic supplementation on growth performance and carcass characteristics of broiler chicks. Egypt. Poult. Sci. 24, 2004, 896-899.

Table 1: Dietary composition of starter broilers' diets

\begin{tabular}{|c|c|c|c|c|c|}
\hline \multicolumn{6}{|c|}{ Dietary Acha replacements levels } \\
\hline Ingredients & T1 & $\mathbf{T} 2$ & T3 & T4 & T5 \\
\hline Maize & 51.80 & 38.85 & 25.90 & 12.95 & 0.00 \\
\hline Acha grains & 0.00 & 12.95 & 25.90 & 38.85 & 51.80 \\
\hline Soybean meal & 35.00 & 35.00 & 35.00 & 35.00 & 35.00 \\
\hline Palm kernel cake & 8.00 & 8.00 & 8.00 & 8.00 & 8.00 \\
\hline Bone meal & 4.00 & 4.00 & 4.00 & 4.00 & 4.00 \\
\hline Anti-mold ${ }^{+}$ & 0.20 & 0.20 & 0.20 & 0.20 & 0.20 \\
\hline *Vit-Min Premix & 0.25 & 0.25 & 0.25 & 0.25 & 0.25 \\
\hline Common Salt & 0.25 & 0.25 & 0.25 & 0.25 & 0.25 \\
\hline Methionine & 0.30 & 0.30 & 0.30 & 0.30 & 0.30 \\
\hline Lysine & 0.20 & 0.20 & 0.20 & 0.20 & 0.20 \\
\hline \multicolumn{6}{|c|}{ Calculated nutrients (\% DM) } \\
\hline Crude protein & 22.20 & 22.45 & 22.75 & 22.85 & 23.00 \\
\hline Crude fibre & 3.57 & 4.06 & 4.32 & 5.50 & 5.68 \\
\hline Ether extract & 3.24 & 3.53 & 4.00 & 4.76 & 5.01 \\
\hline $\mathrm{Ca}(\%)$ & 1.20 & 1.26 & 1.28 & 1.30 & 1.33 \\
\hline $\mathrm{P}(\%)$ & 0.75 & 0.80 & 0.82 & 0.85 & 0.86 \\
\hline Lysine $(\%)$ & 1.42 & 1.45 & 1.48 & 1.49 & 1.52 \\
\hline Methionine(\%) & 0.45 & 0.47 & 0.50 & 0.54 & 0.57 \\
\hline $\mathrm{ME}(\mathrm{Kcal} / \mathrm{Kg})$ & 2897.81 & 2905.65 & 2964.32 & 2987.33 & 3002.00 . \\
\hline \multicolumn{6}{|c|}{ Analyzed compostion (\% DM basis) } \\
\hline Crude protein & 21.40 & 21.60 & 21.90 & 22.18 & 22.44 \\
\hline Crude fibre & 4.28 & 4.30 & 5.46 & 5.53 & 5.60 \\
\hline Ether extract & 3.78 & 4.10 & 4.43 & 4.75 & 5.07 \\
\hline Ash & 4.21 & 4.69 & 5.18 & 5.26 & 5.32 \\
\hline NFE & 53.36 & 53.31 & 51.26 & 50.94 & 49.11 \\
\hline $\mathrm{ME}(\mathrm{Kcal} / \mathrm{kg})^{*}$ & 3036.18 & 3043.45 & 3044.76 & 3045.88 & 3047.77 \\
\hline $\begin{array}{l}\text { Tannins } \\
(\mathrm{mg} / 100 \mathrm{~g})^{*}\end{array}$ & - & 0.02 & 0.05 & 0.07 & 0.09 \\
\hline $\begin{array}{l}\text { Phytate } \\
(\mathrm{mg} / 100 \mathrm{~g})^{*}\end{array}$ & - & 0.13 & 0.27 & 0.40 & 0.53 \\
\hline
\end{tabular}


Performance and carcass and organ weights of broiler chicks fed graded levels of Acha grains

\begin{tabular}{|c|c|c|c|c|c|}
\hline $\begin{array}{l}\text { Oxalate } \\
(\mathrm{mg} / 100 \mathrm{~g})^{*}\end{array}$ & - & $\begin{array}{c}0.12 \\
\end{array}$ & 0.23 & 0.35 & "0.47 \\
\hline $\begin{array}{l}\text { Cyanide } \\
(\mathrm{mg} / 100 \mathrm{~g})^{*}\end{array}$ & - & 0.01 & 0.01 & 0.02 & 0.03 \\
\hline
\end{tabular}

* Premix supplied ( $\mathrm{kg}^{-1}$ diet): Vitamin A (15,000 I.U); Vitamin D3 (3,000 I.U); Vitamin E (30 I. U): Vitamin K (2.5mg); Thiamin (2mg); Riboflavin (6mg); Pyridoxine (4mg); Niacin (40mg); Cobalamin (0.02mg); Pantothenic acid $(910 \mathrm{mg})$; Folic acid $(0.06 \mathrm{~g})$; Iron $(0.024 \mathrm{~g})$; Copper $(0.006 \mathrm{~g})$; Iodine $(0.0014 \mathrm{~g})$; Selenium $(0.24 \mathrm{mg})$; Cobalt $(0.024 \mathrm{mg})$; Antioxidant $(0.125 \mathrm{~g}) ;{ }^{+}$Anti-mold (Anti-mycotoxin).

Calculated* values

Table 2: Dietary composition of Broiler finisher diets

\begin{tabular}{lcllll} 
Ingredients & $\mathbf{T}_{\mathbf{1}}$ & $\mathbf{T}_{\mathbf{2}}$ & $\mathbf{T}_{\mathbf{3}}$ & $\mathbf{T}_{\mathbf{4}}$ & $\mathbf{T}_{\mathbf{5}}$ \\
Maize & $\mathbf{5 1 8 0}$ & $\mathbf{3 8 . 8 5}$ & $\mathbf{2 5 9 0}$ & $\mathbf{1 2 9 5}$ & 0 00 \\
\hline Acha grains & 0.00 & 12.97 & 25.95 & 38.93 & 51.90 \\
Soybean meal & 29.00 & 29.00 & 29.00 & 29.00 & 29.00 \\
Palm kernel cake & 14.00 & 14.00 & 14.00 & 14.00 & 14.00 \\
Bone meal & 4.00 & 4.00 & 4.00 & 4.00 & 4.00 \\
Anti-mold & 0.20 & 0.20 & 0.20 & 0.20 & 0.20 \\
Vit-Min Premix & 0.25 & 0.25 & 0.25 & 0.25 & 0.25 \\
Common Salt & 0.25 & 0.25 & 0.25 & 0.25 & 0.25 \\
Methionine & 0.20 & 0.20 & 0.20 & 0.20 & 0.20 \\
Lysine & 0.20 & 0.20 & 0.20 & 0.20 & 0.20 \\
Total & $\mathbf{1 0 0}$ & $\mathbf{1 0 0}$ & $\mathbf{1 0 0}$ & $\mathbf{1 0 0}$ & $\mathbf{1 0 0}$ \\
Calculated nutrients & & & & & \\
CrudeProtein(\%) & 19.00 & 19.10 & 19.45 & 19.80 & 20.05 \\
Crude fibre(\%) & 4.62 & 5.47 & 6.32 & 7.17 & 7.95 \\
Ether extract (\%) & 3.94 & 4.26 & 4.58 & 4.91 & 5.23 \\
Ca (\%) & 1.21 & 1.27 & 1.28 & 1.32 & 1.34 \\
P (\%) & 0.65 & 0.70 & 0.72 & 0.75 & 0.76 \\
ME (Kcal/Kg) & 2869.72 & 2885.13 & 2901.42 & 2917.20 & 2933.10 \\
\hline P & &
\end{tabular}

Premix supplied ( $\mathrm{kg}^{-1}$ diet): Vitamin A (15,000 I.U); Vitamin D3 (3,000 I.U); Vitamin E (30 I. U): Vitamin K (2.5mg); Thiamin (2mg); Riboflavin (6mg); Pyridoxine (4mg); Niacin (40mg); Cobalamin (0.02mg); Pantothenic acid $(910 \mathrm{mg})$; Folic acid $(0.06 \mathrm{~g})$; Iron $(0.024 \mathrm{~g})$; Copper $(0.006 \mathrm{~g})$; Iodine $(0.0014 \mathrm{~g})$; Selenium $(0.24 \mathrm{mg})$; Cobalt $(0.024 \mathrm{mg})$; Antioxidant $(0.125 \mathrm{~g}) ;{ }^{+}$Anti-mold (Anti-mycotoxin).

Table 3: Effect of diets on growth performance of finisher broiler chickens

\begin{tabular}{lllllll}
\hline Parameters & $\mathbf{T}_{\mathbf{1}}(\mathbf{0 \%})$ & $\mathbf{T}_{\mathbf{2}} \mathbf{( 2 5 \% )}$ & $\mathbf{T}_{\mathbf{3}} \mathbf{( 5 0 \% )}$ & $\mathbf{T}_{\mathbf{4}} \mathbf{( 7 5 \% )}$ & $\mathbf{T}_{\mathbf{5}}(\mathbf{1 0 0 \%})$ & $\mathbf{S E M}$ \\
\hline Initial body weight, g/bird & 100.70 & 101.25 & 101.07 & 101.43 & 103.21 & 0.07 \\
Final body weight, g/bird & $2740.00^{\mathrm{c}}$ & $2829.67^{\mathrm{bc}}$ & $2838.00^{\mathrm{bc}}$ & $3023.33^{\mathrm{a}}$ & $2986.00^{\mathrm{ab}}$ & 72.21 \\
Total weight gain, g/bird & $2639.30^{\mathrm{e}}$ & $2128.42^{\mathrm{d}}$ & $2736.93^{\mathrm{c}}$ & $2921.90^{\mathrm{a}}$ & $2882.79^{\mathrm{b}}$ & 34.70 \\
Total feed intake, g/bird & $4825.00^{\mathrm{c}}$ & $4807.14^{\mathrm{b}}$ & $4724.40^{\mathrm{d}}$ & $4903.70^{\mathrm{c}}$ & $4927.65^{\mathrm{a}}$ & 0.92
\end{tabular}

$a, b, c, d, e$ Means on the same row with different superscripts are significantly $(\mathrm{p}<0.05)$ different.

Table 4: Apparent nutrient digestibility coefficient of broiler finisher fed experimental diets (\% DM basis)

\begin{tabular}{lcccccc}
\hline & \multicolumn{7}{c}{ Diets } & \\
\cline { 2 - 5 } Nutrients & $\mathbf{T}_{\mathbf{1}}$ & $\mathbf{T}_{\mathbf{2}}$ & $\mathbf{T}_{\mathbf{3}}$ & $\mathbf{T}_{\mathbf{4}}$ & $\mathbf{T}_{\mathbf{5}}$ & SEM \\
\hline Dry matter (\%) & 78.35 & 78.86 & 77.45 & 78.72 & 78.40 & 0.12 \\
Crude protein (\%) & 77.49 & 73.95 & 77.57 & 73.17 & 74.85 & 0.05 \\
Crude fibre (\%) & 40.67 & 40.54 & 45.21 & 45.26 & 46.29 & 0.22 \\
Ash (\%) & 56.99 & 55.57 & 58.26 & 56.20 & 55.78 & 0.34 \\
Ether extract (\%) & $87.04^{\mathrm{a}}$ & $79.42^{\mathrm{ab}}$ & $77.17^{\mathrm{b}}$ & $76.38^{\mathrm{b}}$ & $78.20^{\mathrm{b}}$ & 0.42 \\
Nitrogen free extract & 79.14 & 79.22 & 80.40 & 72.43 & 72.68 & 0.11 \\
$(\%)$ & & & & & & \\
\hline
\end{tabular}

a,b Means on the same row with different superscripts are significantly $(\mathrm{P}<0.05)$ different. 
Performance and carcass and organ weights of broiler chicks fed graded levels of Acha grains Table 5: Carcass characteristics of broiler chickens fed diets containing Acha grains

\begin{tabular}{lllllll}
\hline & \multicolumn{7}{c}{ Diets } \\
\cline { 2 - 6 } Parameters & \multicolumn{1}{c}{$\mathbf{T}_{\mathbf{1}}$} & \multicolumn{1}{c}{$\mathbf{T}_{\mathbf{2}}$} & \multicolumn{1}{c}{$\mathbf{T}_{\mathbf{3}}$} & \multicolumn{1}{c}{$\mathbf{T}_{\mathbf{4}}$} & \multicolumn{1}{c}{$\mathbf{T}_{\mathbf{5}}$} & $\mathbf{S E M}$ \\
\hline Live weight/bird (g) & $2740.00^{\mathrm{d}}$ & $2829.67^{\mathrm{c}}$ & $2838.00^{\mathrm{c}}$ & $3023.33^{\mathrm{a}}$ & $2986.00^{\mathrm{b}}$ & 72.21 \\
Carcass weight (\%) & 68.14 & 67.97 & 68.98 & 66.89 & 68.90 & 0.23 \\
Thigh (\%) & 17.91 & 17.99 & 17.64 & 17.10 & 17.50 & 0.20 \\
Drumstick (\%) & 18.12 & 18.41 & 18.25 & 17.73 & 18.10 & 0.34 \\
Breast (\%) & 27.89 & 27.60 & 28.44 & 28.22 & 28.37 & 0.14 \\
Back (\%) & 23.25 & 23.02 & 23.06 & 23.00 & 23.82 & 0.02 \\
Neck (\%) & 4.43 & 4.89 & 4.69 & 4.53 & 4.30 & 0.50 \\
Shank (\%) & 3.84 & 3.82 & 4.21 & 3.62 & 4.00 & 0.06 \\
Wings (\%) & 13.18 & 13.64 & 13.26 & 13.93 & 13.24 & 0.06 \\
Head (\%) & 2.67 & 2.35 & 2.23 & 2.21 & 2.46 & 0.08 \\
Abdominal (\%) & $0.96^{\mathrm{c}}$ & $1.09^{\mathrm{b}}$ & $1.19^{\mathrm{b}}$ & $1.13^{\mathrm{b}}$ & $1.45^{\mathrm{a}}$ & 0.02 \\
\hline
\end{tabular}

$a, b, c, d$ Means on the same row with different superscripts are significantly $(\mathrm{P}<0.05)$ different.

Table 6: Organ characteristics of broiler chickens fed diets containing Acha grains

\begin{tabular}{lllllll}
\hline & \multicolumn{7}{c}{ Diets } \\
\cline { 2 - 7 } Parameters & $\mathbf{T}_{\mathbf{1}}$ & $\mathbf{T}_{\mathbf{2}}$ & $\mathbf{T}_{\mathbf{3}}$ & $\mathbf{T}_{\mathbf{4}}$ & $\mathbf{T}_{\mathbf{5}}$ & $\mathbf{S E M}$ \\
\hline Heart (\%) & 0.49 & 0.42 & 0.49 & 0.61 & 0.43 & 0.27 \\
Kidney (\%) & 0.71 & 0.65 & 0.59 & 0.60 & 0.64 & 0.06 \\
Lungs (\%) & 0.62 & 0.53 & 0.55 & 0.62 & 0.50 & 0.02 \\
Liver (\%) & $1.88^{\mathrm{c}}$ & $1.72^{\mathrm{d}}$ & $1.97^{\mathrm{b}}$ & $2.03^{\mathrm{a}}$ & $1.98^{\mathrm{b}}$ & 0.05 \\
Pancreas (\%) & 0.21 & 0.23 & 0.29 & 0.29 & 0.27 & 0.22 \\
Gizzard (\%) & $2.07^{\mathrm{c}}$ & $2.13^{\mathrm{b}}$ & $2.13^{\mathrm{b}}$ & $2.21^{\mathrm{a}}$ & $2.18^{\mathrm{a}}$ & 0.17 \\
Spleen (\%) & 0.15 & 0.12 & 0.18 & 0.17 & 0.18 & 0.03 \\
Proventriculus (\%) & $0.40^{\mathrm{cb}}$ & $0.48^{\mathrm{ab}}$ & $0.44^{\mathrm{b}}$ & $0.54^{\mathrm{a}}$ & $0.53^{\mathrm{a}}$ & 0.01 \\
Intestinal length wt (\%) & 3.32 & 3.24 & 3.16 & 3.24 & 3.23 & 0.10 \\
\hline
\end{tabular}

$\mathrm{a}, \mathrm{b}, \mathrm{c}, \mathrm{d}$ Means on the same row with different superscripts are significantly $(\mathrm{P}<0.05)$ different. 